\title{
Perbincangan Tentang Pendidikan Islam Di Indonesia
}

\author{
H. Muhaimin \\ Pj. Pembantu Rektor I Universitas Islam Indonesia Sudan \\ (UIIS) Malang d/h STAIN Malang
}

\section{Abstract}

The Indonesian people and government, which had inherited the dualistic education system, both the colonial education and Islamic educational systems, did not give priority to one of them, but they endeavored to integrate it to be "a national educational system". Delivering religious education systematically in public schools (the secular and colonial schools system) was the one to make them religious and cultural based schools system. Giving a help and guide to Madrasah and Pesantren enhances them in sharpening human life and in developing themselves to be integrated in a national educational system. The ratification of UU No. $2 / 1989$ about National Educational System showed that the integration had got a strong law foundation. So, the religious education must be delivered in each lanes, kinds and levels of education.

The discourse of Islamic educational thought, as found in some Islamic education literatures, focused on four issues, i.e.: dichotomy of the perennial knowledge and the acquired knowledge, deriving the Islamization of knowledge issues (including education); quality of religious education in schools and universities, especially in operational dimensions; the development of Islamic education integratedly to build the integrity of human being; discovering the philosophical concepts of Islamic education and the figures' thoughts of it from classical and medieval ages to modern period. Such phenomena will be able to empower the Islamic education as a discipline of science, which has a specific and systematic object as well as the methodology of study. 


\section{A. Pendahuluan}

Akhir-akhir ini banyak bermunculan Program Pascasarjana (S2 \& S3), baik di UIN/IAIN/STAIN maupun Perguruan Tinggi Islam Swasta, yang mengembangkan konsentrasi "Pendidikan Islam". Kehadirannya patut disambut dengan gembira, karena darinya diharapkan bangkitnya gerakan-gerakan pemikiran baru di bidang pendidikan Islam, sebagai upaya menggali pemikiran-pemikiran alternatif serta memberikan kontribusi dalam mengantisipasi persoalan pendidikan nasional, terutama dalam konteks pembangunan bangsa Indonesia yang sedang mengalami krisis multidimensional.

Pendidikan memang merupakan kunci kemajuan, semakin baik kualitas pendidikan yang diselenggarakan oleh suatu masyarakat/bangsa, maka akan diikuti dengan semakin baiknya kualitas masyarakat/bangsa tersebut. Tidak salah jika Fazlurrahman menyatakan bahwa "setiap reformasi dan pembaharuan dalam Islam harus dimulai dengan pendidikan"'. Karena itu, para pemerhati dan pengembang pendidikan Islam tiada henti-hentinya untuk memperbincangkan masalah tersebut.

Khursid Ahmad (dalam Ismail, 1996) misalnya menyatakan bahwa: "Of all the problem that confront the muslim world today the educational problem is the most challenging. The future of the muslim world will depend upon the way it responds to this challenge", yakni dari sekian banyak perma-salahan yang merupakan tantangan terhadap dunia Islam dewasa ini, maka masalah pendidikan merupakan masalah yang paling menantang. Masa depan dunia Islam tergantung kepada cara bagaimana dunia Islam menjawab dan memecahkan tantangan ini. ${ }^{2}$ Statement ini menggarisbawahi bahwa masa depan Islam di Indonesia juga bergantung kepada bagaimana cara umat Islam merespon dan memecahkan masalah-masalah pendidikan yang berkembang di Indonesia, terutama dalam konteks pengem-bangan sistem pendidikan Islam di masa depan.

Apa saja persoalan-persoalan pendidikan Islam yang menjadi bahan pemikiran, kajian dan perbincangan di kalangan para pakar, pemerhati dan pengembang pendidikan Islam sejak Indonesia merdeka hingga sekarang. Hal inilah yang menjadi fokus perhatian dalam kajian ini. Melalui telaah historis dan kajian terhadap literaturliteratur kependidikan Islam yang telah terpublikasikan hingga akhir-akhir ini, diharap-kan dapat ditemukan berbagai persoalan yang perlu ditelaah lebih lanjut guna pengembangan pendidikan Islam yang lebih prospektif dan antisipatif. 


\section{B. Integrasi Sistem Pendidikan Islam ke Dalam Sistem Pendidikan Nasional}

Pada masa awal kemerdekaan, pemerintah dan bangsa Indonesia telah mewarisi sistem pendidikan dan pengajaran yang dualistis, yaitu: (1) sistem pendidikan dan pengajaran pada sekolah-sekolah umum yang sekuler, tak mengenal ajaran agama, yang merupakan warisan dari pemerintah kolonial Belanda; dan (2) sistem pendidikan dan pengajaran Islam yang tumbuh dan berkembang di kalangan masyarakat Islam sendiri, baik yang bercorak isolatif-tradisiona ${ }^{\beta}$ maupun yang ber-corak sintesi $s^{4}$ dengan berbagai variasi pola pendidikannya.

Kedua sistem pendidikan tersebut sering dianggap saling bertentangan set: tumbuh dan berkembang secara terpisah satu sama lain. Sistem pendidikan dar pengajaran yang pertama pada mulanya hanya menjangkau dan dinikmati oleh sebagian kalangan masyarakat, terutama kalangan atas saja ${ }^{5}$. Sedangkan yang kedua (sistem pendidikan dan penga-jaran Islam) tumbuh dan berkembang secara mandiri di kalangan rakyat dan berurat berakar dalam masyarakat ${ }^{6}$. Hal ini diakui oleh Badan Pekerja Komite Nasional Indonesia Pusat (BP-KNIP) dalam usul rekomendasinya yang disampaikan kepada pemerintah, tentang Rencana PokokPokok Pendidikan dan Pengajaran Baru, pada tanggal 29 Desember 1945.

Bangsa Indonesia yang mayoritas penduduknya beragama Islam telah bertekad untuk membentuk satu negara kesatuan Republik Indonesia (RJ) yang berdasarkan Pancasila dan UUD 1945. ${ }^{7}$ Perwujudan tekad ini secara formal untuk pertama kalinya dirumuskan dalam suatu Piagam yang ditandatangani oleh tokohtokoh bangsa Indonesia (termasuk tokoh-tokoh umat Islam) pada tanggal 22 Juni 1945. Piagam ini kemudian diken-al dengan sebutan Piagam Jakarta, yang dengan sedikit peru-bahan namun mendasar, kemudian dijadikan Pembukaan UndangUndang Dasar 1945. Walaupun negara kesatuan RI yang dibentuk itu bukan negara yang berdasarkan Islam, namun Pancasila dan UUD 1945 sebagai dasar negara dijiwai oleh Piagam Jakarta, yang mewajibkan kepada umat Islam untuk melaksanakan syariat agamany ${ }^{8}$, dan untuk itu cukup mendapatkan jaminan dalam ketentuan UUD 1945 itu sendiri'. Dengan demikian sistem pendidikan Islam yang ada dan telah berkembang pada masa itu, sebagai salah satu bentuk dan usaha pelaksanaan syariat Islam, mendapat kesempatan dan jaminan untuk tetap berlang-sung dan berkembang, serta mendapatkan perhatian dan bantuan dari 
pemerintah. Menurut ajaran Islam, pendidikan merupakan bagian hakiki dari tugas pengabdian (ibadah) dan kekhalifahan manusia terhadap Tuhan, yang harus dilaksanakan dengan penuh tanggungjawab. Seruan BP KNIP pada tanggal 22 Desember 1945 yang menyatakan "agar dalam memajukan pendidikan dan penga-jaran, sekurang-kurangnya diusahakan agar pengajian di langgar-langgar dan madrasah berjalan terus dan diperpesat", sejalan dengan pengertian tersebut. ${ }^{10}$

Pasal 31 ayat 2 UUD 1945 menyatakan bahwa "Pemerintah mengusahakan dan menyelenggarakan satu sistem pengajaran nasional yang diatur dengan undangundang". Mengapa para pendiri bangsa dan negara RI mengamanatkan demikian kepada pemerintah, padahal kenyataan yang ada menunjukkan bahwa bangsa Indonesia mewarisi sistem pendidikan yang bersifat dualistis? Lalu apa yang dimaksudkan dengan satu sistem pengajaran nasional tersebut? dan sistem pendidikan mana yang akan dikembangkan oleh pemerintah, apakah sistem pendi-dikan dan pengajaran modern warisan pemerintah kolonial, atau sistem pendidikan Islam warisan dari umat Islam, atau perpaduan antara keduanya? Hal ini dirumuskan dan diatur secara terperinci dalam Undang-undang yang akan ditetapkan kemudian.

Undang-undang yang mengatur penyelenggaraan satu sistem pengajaran nasional ternyata tidak dapat diwujudkan dengan segera. Namun demikian PPKI bidang Pendidikan Penga-jaran dan Kebudayaan" telah merumuskan "Rencana Pokok-pokok Pendidikan Pengajaran dan Kebudayaan", yang dimaksud-kan sebagai pedoman bagi penyelenggaraan satu sistem pendi-dikan dan pengajaran nasional sebagaimana yang dikehendaki oleh pasal 31 UUD 1945 tersebut. Panitia tersebut diketuai oleh tokoh pendidikan bangsa Indonesia, yang terkenal seba-gai tokoh pendidikan nasional, yaitu Ki Hajar Dewantara, dengan anggota-anggotanya terdiri atas: Dr. Asikin, Ir. Rooseno, Ki Bagus Hadikusuma dan KH. Mas Mansur.

Di dalam Rencana Pokok-pokok Pendidikan Pengajaran dan Kebudayaan tersebut dirumuskan antara lain:

1) Dengan undang-undang kewajiban belajar, atau perat-uran lain jika keadaan di suatu daerah memaksanya, pemerintah memelihara pendidikan kecerdasan akal budi untuk segenap rakyat dengan cukup dan sebaik-baiknya seperti ditetapkan dalam UUD 1945 pasal 31. 
2) Dalam garis-garis adab perikemanusiaan, seperti terkandung dalam segala pengajaran agama, maka pendidikan dan pengajaran nasional bersendi agama dan kebudayaan bangsa serta menuju ke arah kesela-matan dan kebahagiaan masyarakat.

3) Kebudayaan bangsa adalah kebudayaan yang timbul sebagai buah usaha budidaya rakyat Indonesia selur-uhnya. Kebudayaan lama dan aseli yang terdapat sebagai puncak-puncak kebudayaan di seluruh Indone-sia, terhitung sebagai kebudayaan bangsa. Usaha kebudayaan harus menuju ke arah kemajuan adab, budaya dan persatuan bangsa, dengan tidak menolak bahanbahan baru dari kebudayaan asing, yang dapat memperkembang atan memperkaya kebudayaan bangsa sendiri, serta mempertinggi derajat kemanusiaan bangsa Indonesia.

4) Untuk dapat memperhatikan serta memelihara kepen-tingan-kepentingan khusus dengan sebaik-baiknya, teristimewa yang berdasarkan agama dari atau kebu-dayaan bangsa, maka fihak rakyat diberi kesempatan yang cukup luas untuk mendirikan sekolah-sekolah partikelir, yang penyelenggaraannya sebagian atau sepenuhnya boleh dibiayai oleh pemerintah.

5) Tentang susunan pelajaran pengetahuan dan kepan-daian umum harus ditetapkan suatu daftar pelajaran sedikit-dikitnya (minimum leerplan), yang menetap-kan luas tingginya pelajaran pengetahuan dan kepandaian umum, serta pula pendidikan budi pekerti, teristimewa pendidikan semangat bekerja, kekeluar-gaan, cinta tanah air, serta keprajuritan. Syarat-syarat itu diwajibkan untuk semua sekolah, baik kepunyaan negeri maupun partikelir. ${ }^{12}$

Rumusan tersebut cukup memberikan gambaran yang jelas tentang apa yang dimaksud dengan satu sistem pengajaran nasional yang dikehendaki oleh pasal 31 UUD 1945. Dengan pernyataan bahwa "pendidikan dan pengajaran nasional bersen-di agama dan kebudayaan bangsa serta menuju ke arah kesela-matan dan kebahagiaan masyarakat", dan bahwa "usaha kebu-dayaan harus menuju ke arah kemajuan adab, budaya dan per-satuan bangsa", nampaknya para pendiri bangsa dan negara ini ingin menekankan bahwa yang dikehendaki dengan satu sistem pengajaran nasional bukanlah sistem pendidikan dan pengajar-an warisan pemerintah kolonial Belanda yang bercorak sekuler dan netral terhadap agama, tetapi bukan pula sistem pendidikan Islam warisan dari umat Islam. Nampaknya mereka menghen-daki terjadinya perpaduan atau integrasi antara kedua sistem pendidikan 
dan pengajaran warisan budaya bangsa tersebut menjadi "satu sistem pendidikan nasional". ${ }^{13}$

Kehendak untuk mengintegrasikan itu semakin jelas ketika BP-KNIP mengusulkan rencana tentang "Pokok-pokok Pendidikan dan Pengajaran Baru" pada tanggal 25 Desember 1945, yang isinya antara lain:

2. Untuk memperkuat persatuan rakyat kita hendaknya diadakan satu macam sekolah untuk segala lapisan masyarakat. Perlu diingat pula bahwa sesuai dengan dasar keadilan sosial, semua sekolah harus terbuka untuk tiap-tiap penduduk negara baik laki-laki maupun perempuan.

4a. Pengajaran agama hendaklah mendapat tempat yang teratur seksama, hingga cukup mendapat perhatian yang semestinya, dengan tidak mengurangi kemerde-kaan golongan-golongan yang berkehendak mengikuti kepercayaan yang dipeluknya.

4b. Madrasah dan Pesantren-pesantren yang pada hakekatnya adalah satu alat dan sumber pendidikan dan pencerdasan rakyat jelata, yang sudah berurat berakar dalam masyarakat Indonesia umumnya, hendak-lah pula mendapat perhatian dan bantuan yang nyata dengan berupa tuntunan dan bantuan materiil dari pemerintah. ${ }^{14}$

Usul dari BP-KNIP "hendaknya diadakan satu macam sekolah untuk segala lapisan masyarakat" jelas mempertegas kehendak untuk menyatukan atau mengintegrasikan kedua sistem pendidikan warisan budaya bangsa tersebut. Pemberian penga-jaran agama secara teratur seksama di sekolah-sekolah, tentunya dimaksudkan agar sekolah-sekolah yang pada mulanya bersifat sekuler dan netral terhadap agama serta bercorak kolonial, menjadi sekolah-sekolah yang bersendi agama dan kebudayaan bangsa, sebagaimana dikehendaki oleh pendiri bangsa dan negara ini. Sedangkan pemberian tuntunan dan bantuan kepada madrasah dan pesantren-pesantren dimaksudkan agar lembaga pendidikan Islam mampu meningkatkan usaha dan peran sertanya dalam dan sebagai alat pendidikan dan pencer-dasan kehidupan bangsa, serta mampu berkembang dan mengada-kan pembaharuan secara terintegrasi dalam satu sistem pendi-dikan nasional.

Walaupun undang-undang yang mengatur pelaksanaan dan penyelenggaraan satu sistem pendidikan dan pengajaran na-sional tidak dengan segera dapat terwujud, tetapi hal itu tidak berarti bahwa usaha untuk mengadakan pembaharuan dan 
mengintegrasikan pendidikan Islam ke dalam sistem pendidikan nasional, tidak atau belum berlangsung. Ternyata semua aturan perundang-undangan dan kebijaksanaan serta praktik penyelenggaraan pendidikan nasional yang dilaksanakan oleh Pemerintah RI, nampak mengarah dan sebagai usaha untuk mewujudkan integrasi atau untuk terwujudnya satu sistem pendidikan nasional sebagaimana yang dikehendaki oleh UUD 1945, dengan memberikan wadah dan kesempatan kepada lembaga pendidikan Islam untuk berkembang secara terintegrasi ke dalamnya. Dalam hal ini sangat terkait dengan peran Departemen Agama (Depag) yang mulai resmi berdiri tanggal 3 Januari 1946. Lembaga ini secara intensif memperjuangkan politik pendidikan Islam di Indonesia. Orientasi usahanya dalam bidang pendidikan Islam bertumpu pada aspirasi umat Islam agar pendidikan agama diajarkan di sekolah-sekolah, di samping pada pengembangan Madrasah. Secara lebih spesifik, usaha ini ditangani oleh satu bagian khusus yang mengurusi masalah pendidikan agama. Dalam salah satu dokumen disebut-kan bahwa tugas bagian pendidikan di lingkungan Depag meli-puti: (1) memberi pengajaran agama di sekolah negeri dan partikelir; (2) memberi pengetahuan umum di Madrasah; dan (3) mengadakan Pendidikan Guru Agama (PGA) dan Pendidikan Hakim Islam Negeri (PHIN). ${ }^{15}$

Undang-Undang No. 4 tahun 1950, tentang Dasar-Dasar Pendidikan dan pengajaran di Sekolah, memberikan kesempatan untuk masuknya pengajaran agama di sekolah-sekolah, di samping mengakui sekolah agama (Madrasah, yang diakui oleh Menteri Agama) sebagai lembaga penyelenggara kewajiban belajar. Tap MPRS No. 2 tahun 1960 menetapkan: "pemberian pelajaran agama pada semua tingkat pendidikan, mulai dari sekolah dasar sampai dengan perguruan tinggi negeri". di samping pengakuan bahwa "Pesantren dan Madrasah sebagai lembaga pendidikan yang otonom di bawah pembinaan Departemen Agama. Kemudian Tap MPRS No. 27 tahun 1966, menetapkan bahwa "Agama, Pendidikan dan Kebudayaan" adalah unsur mutlak dalam Nation and Character Building, sekaligus menetapkan bahwa "pendidikan agama menjadi mata pelajaran pokok dan wajib diikuti oleh setiap murid/mahasiswa sesuai dengan agama masing-masing. Selanjutnya pentingnya pembinaan dan pemban-gunan kehidupan keagamaan (termasuk lembaga pendidikan agama) serta pendidikan agama di sekolah-sekolah, dari sekolah dasar sampai dengan perguruan tinggi negeri, selalu masuk dan mendapat perhatian yang seksama dalam GBHN. Ak-himya, Tap MPR No. 2 tahun 1988 tentang "Asas Tunggal", yang menetapkan bahwa "Pancasila adalah 
satu-satunya asas" bagi kehidupan bermasyarakat, berbangsa dan bernegara, lebih memantapkan usaha masuknya lembaga pendidikan keagamaan (pesantren dan madrasah) dalam kerangka sistem pendidikan nasional. Dengan demikian, lebih memantapkan pula usaha mengintegrasikan pendidikan Islam ke dalam sistem pendidikan nasional.

Segala peraturan perundang-undangan dan kebijaksanaan yang dibuat oleh pemerintah, yang nampaknya mengarah kepada usaha integrasi tersebut, merupakan persiapan untuk menyusun dan mewujudkan undang-undang tentang "satu sistem pendidikan dan pengajaran nasional" sebagaimana dikehendaki oleh pasal 31 UUD 1945. Dengin telah disahkannya UU No. 2 tahun 1989, tentang Sistem Pendidikan Vasional, maka usaha integrasi pendidikan Islam ke dalam sistem pendidikan nasional menda-patkan dasar hukumnya yang mantap. Sejak disahkannya UU ini, maka isi kurikulum setiap jenis, jalur dan jenjang pendidi-kan wajib memuat pendidikan agama, dan Madrasah dinyatakan sebagai sekolah umum yang berciri khas agama Islam.

Berbagai uraian tersebut di atas menggambarkan betapa perhatian dan pengakuan bangsa Indonesia terhadap sumbangan besar pendidikan Islam dalam upaya mendidik dan mencerdaskan kehidupan bangsa. Perhatian dan pengakuan tersebut merupakan tantangan yang memerlukan respon positif dari para pemikir dan pengelola pendidikan Islam di Indonesia.

\section{Wacana Pendidikan Islam Yang Berkembang Dalam Literatur Kependidikan Islam}

Dari hasil telaah penulis terhadap literatur-literatur kependidikan Islam, menunjukkan bahwa wacana yang berkembang dalam pemikiran pengembangan pendidikan Islam setidak-tidaknya dapat dipetakan ke dalam 4 (empat) persoalan: (1) dikotomi ilmu pengetahuan hingga memunculkan masalah islami-sasi ilmu pengetahuan (pendidikan); (2) kualitas pendidikan agama Islam di sekolah dan perguruan tinggi umum; (3) upaya membangun pendidikan Islam secara terpadu untuk mengembangkan manusia Indonesia seutuhnya, yang beriman dan bertaqwa kepada Tuhan Yang Maha Esa, cerdas, terampil, berakhlak mulia, kuat kepribadian, cinta tanah air, tebal semangat kebangsaannya; (4) penggalian konsep pemikiran filosofis pendidikan Islam serta pemikiran para tokoh pendidikan Islam mulai periode klasik hingga periode modern, baik dari dalam maupun luar negeri.

Ulul Albab, Vol. 3 No. 2, 2001 
Sehubungan dengan persoalan pertama, bahwa problem dikotomi antara pendidikan agama dan pendidikan umum atau antara ilmu agama dan ilmu umum sebenarnya muncul sejak sebelum Indonesia merdeka, tetapi problem ini masih berkem-bang hingga sekarang. Hal ini setidak-tidaknya dapat dilacak dari kajiankajian kependidikan Islam baik melalui kegiatan seminar maupun dalam buku-buku ilmiah. Seminar nasional tentang "Islam dan Pendidikan Nasional" yang diselenggarakan oleh IAIN Jakarta tanggal 25 - 27 April 1983 antara lain merekomendasikan bahwa pendidikan haruslah dilakukan tanpa bersifat dikotomis terhadap sains dan ilmu agama, karena dalam sejarahnya ulama-ulama Islam terdahulu tidal mempunyai sikap dikotomi. ${ }^{16}$ Buchori, justeru mempertanyakan keabsahan dikotomi yang memisahkan pendidikan agama dari pendidikan umum. Menurut pandangannya bahwa dikotomi terse-but hanya merupakan dikotomi illusif, yakni dikotomi yang lahir dari kedangkalan persepsi kita mengenai hakekat proses pendidikan agama dan pendidikan umum sebagai dua kegiatan yang konvergen, yang sama-sama bermuara pada pengembangan diri siswa, pada penanaman suatu tata nilai, yaitu tata nilai Islam pada diri para siswa. ${ }^{17}$ Dalam antologi kecil berjudul "Pendidikan Islam di Indonesia Antara Cita dan Fakta", sebagian besar penulis menyoroti persoalan dikotomi tersebut. Masalah dikotomi itu antara lain disoroti oleh Muslich Usa dengan tema "Pendidikan Islam di Indonesia Antara Cita dan Fakta", Amrullah Achmad dengan tema "Kerang-ka Dasar Masalah Paradigma Pendidikan Islam", Ahmad Watik Pratiknya dengan tema "Identifikasi Masalah Pendidikan Agama Islam di Indonesia", Achmad Syafii Maarif dengan tema "Pemikiran tentang Pembaharuan Pendidikan Islam di Indonesia". ${ }^{18}$

Bersamaan dengan problem dikotomi tersebut muncul pula perbincangan tentang islamisasi ilmu pengetahuan, termasuk di dalamnya ilmu pendidikan, sebagai respon terhadap kriris pendidikan dan ilmu pengetahuan yang sedang diderita oleh umat Islam. Gagasan "Islamisasi Pengetahuan" ini muncul pada saat diselenggarakan sebuah Konperensi Dunia yang pertama tentang Pendidikan Muslim di Mekah pada tahun 1977. Konper-ensi yang diprakarsai dan dilaksanakan oleh King Abdul Aziz University ini berhasil membahas 150 makalah yang ditulis oleh sarjana-sarjana dari 40 negara, dan merumuskan rekomen-dasi untuk pembenahan dan penyempurnaan sistem pendidikan Islam yang diselenggarakan oleh umat Islam di seluruh dunia. Salah satu gagasan yang direkomendasikan adalah menyangkut Islamisasi Pengetahuan. Gagasan ini dilontarkan oleh Syed Muhammad Naquib 
Al-Attas dalam makalahnya yang berjudul "Preliminary Thoughts on the Nature of Knowledge and the Definition and the Aims of Education", dan Ismail Raji al-Faruqi dalam makalahnya "Islamicizing Social Science". Al-Attas menyatakan bahwa tantangan terbesar yang secara diam-diam dihadapi oleh umat Islam pada zaman ini adalah tantan-gan pengetahuan, bukan dalam bentuk sebagai kebodohan, tetapi pengetahuan yang difahamkan dan disebarkan ke seluruh dunia oleh peradaban Barat. Dan menurut Al-Faruqi bahwa sistem pendidikan Islam telah dicetak di dalam sebuah kari-katur Barat, sehingga ia dipandang sebagai inti malaise atau penderitaan yang dialami umat. ${ }^{19}$

Nana-nama cendekiawan muslim Indonesia yang memiliki concern terhadap persoalan tersebut antara lain adalah: A.M. Saefuddin dalam tulisannya "Perspektif Ilmu Pengetahuan dan Kampus yang Islami" dan bukunya "Deseku-larisasi Pemikiran" ; Hidayat Nataat-maja dalam bukunya "Karsa Menegakkan Jiwa Agama dalam Dunia Ilmiah" dan "Krisis Global Ilmu Pengetahuan dan Penyembu-hannya"; Endang Saefuddin Anshari dalam makalahnya "Klasifikasi Ilmu Ditinjau dari Obyek Materinya" (Tak Diterbitkan); Yusuf Amir Feisal sebagai perumus gagasan dan konsep "IDI (Islam Untuk Disiplin Ilmu)" yang kemudian diambil oleh Departemen Agama dan diwujudkan dalam bentuk buku teks untuk pendidikan agama Islam di Perguruan Tinggi; dan Jalaluddin Rahmat dalam bukunya "Islam Aliernatif", khususnya pada halaman 147-226.

Namun demikian, di kalangan cendekiawan muslim agaknya masih terdapat sikap pro dan kontra terhadap Islamisasi Pengetahuan, yang masing-masing pihak memiliki alasan-alasan yang cukup mendasar. Pihak yang pro berargumentasi, bahwa: (1) umat Islam membutuhkan sebuah sistem sains untuk memenu-hi kebutuhan-kebutuhan mereka baik materiil maupun spiritu-al, sedangkan sistem sains yang ada kini belum mampu memenu-hi kebutuhan-kebutuhan tersebut, karena ia banyak mengandung nilai-nilai yang bertentangan dengan Islam; (2) kenyataan membuktikan bahwa sains modern telah menimbulkan ancaman-ancaman bagi kelangsungan dan kehidupan umat manusia dan lingkungannya; dan (3) umat Islam pernah memiliki suatu peradaban Islami, yaitu sains berkembang sesuai dengan nilai-nilai dan kebutuhan umat, sehingga untuk menciptakan kembali sains Islam dalam peradaban yang Islami perlu dila-kukan Islamisasi sains.

Sedangkan pihak yang kontra berargumentasi bahwa dilihat dari segi historis, perkembangan kemajuan ilmu pengetahuan dan teknologi di Barat saat ini banyak 
dillhami oleh para ulama Islam yang ditransformasikan terutama pada "masa keemasan Islam", sehingga mereka banyak berhutang budi terhadap ilmuwan muslim. Karena itu, jika kita hendak meraih kemajuan di bidang iptek, maka kita perlu melakukan transformasi besar-besaran dari Barat tanpa ada rasa curiga, walaupun harus selalu waspada. Iptek adalah netral, ia bergantung kepada pembawa dan pengembangnya. Karena itulah Islamisasi ilmu pengetahuan adalah tidak begitu penting, tetapi yang lebih penting justeru adalah Islamisasi subyek atau pembawa dan pengembang iptek itu sendiri.

Jika dicermati dari argumentasinya, kedua pihak terse-but (pro dan kontra) sebenarnya mempunyai pretensi yang sama, yaitu sama-sama menginginkan terwujudnya kemajuan peradaban yang Islami, dan masing-masing juga tidak menghen-daki terpuruknya kondisi umat Islam di tengah-tengah akse-lerasi perkembangan dan kemajuan iptek. Hanya saja pihak yang pro lebih melihat dimensi ilmu pengetahuan sebagai obyek kajian yang perlu dicarikan landasan filosofisnya yang Islami, sedangkan pihak yang kontra lebih melihat subyeknya atau pembawa dan pengembang iptek itu sendiri yang harus Islami.

Persoalan kedua yang disoroti adalah menyangkut kuali-tas pendidikan agama Islam di Sekolah dan Perguruan Tinggi Umum. Berbagai persoalan mendasar yang diperbincangkan baik dalam buku-buku atau tulisan mengenai pendidikan Islam maupun dalam kegiatan seminar/diskusi atau forum-forum lain, adalah menyangkut problem internal dan eksternal dari pendi-dikan agama Islam.

Aspek internal menyangkut sisi pendidikan agama sebagai program pendidikan terutama dari segi orientasinya yang lebih terkonsentrasi pada persoalanpersoalan teoretis keagamaan yang bersifat kognitif semata serta amalan-amalan ibadah praktis, dan lebih berorientasi pada belajar tentang agama, kurang concern terhadap persoalan bagaimana mengubah pengetahuan agama yang kognitif menjadi "makna" dan "nilai" yang perlu diinternalisasikan dalam diri siswa; sempitnya pemahaman guru/dosen agama terhadap esensi ajaran agama Islam; perancangan dan penyusunan materi PAI yang kurang tepat; metodologinya yang konvensionaltradisional; dan evaluasinya yang juga kognitif, serta pelaksanaan dan penye-lenggaraannya yang masih bersikap eksklusif dan belum mampu berinteraksi dan bersinkronisasi dengan yang lainnya.

Sedangkan aspek eksternal berupa berbagai kemajuan ilmu pengetahuan dan teknologi yang berdampak pada munculnya scientific criticism atau kritik 
ilmu pengetahuan terhadap penjelasan ajaran agama yang bersifat konservatiftradision-al, tekstual dan skripturalistik, era globalisasi di bidang informasi serta perubahan sosial ekonomi dan budaya dengan segala dampaknya; dan kemajemukan masyarakat beragama yang masih belum siap untuk berbeda faham dan justeru cenderung bersikap apologis, fanatik, absolutis, serta truth claim yang dibungkus dalam simpul-simpul interest, baik interes pribadi maupun yang bersifat politis dan sosiologis.

Buku-buku Metodologi Pendidikan atau Pengajaran Agama Islam yang telah disısun oleh para pakar pendidikan Islam baik dari Indonesia maupun Timur Tengah, ternyata belum mampu memberikan tawaran alternatif dalam menjawab berbagai persoalan tersebut. Hal ini di samping karena pendekatannya yang lebih bersifat normatif, dalam arti pengembangan metodologi tersebut dibangun dari pemahaman terhadap nash-nash (wahyu) secara deduktif tanpa memperhatikan kaitannya dengan persoalan pendidikan agama yang tumbuh dan berkembang di lapangan, juga karena miskinnya kegiatan penelitian, uji coba atau eksperimen untuk memperoleh metode-metode yang tepat, efektif, efisien dan memiliki daya tarik, dengan mempertimbangkan dimensi-dimensi kondisional dan kontekstualnya. Pengembangan metodologi pendidikan agama Islam yang ada masih bersifat adopsi dan modifikasi begitu saja dari temuan-temuan metodologi pendidikan atau pengajaran bidang studi lainnya yang lebih bersifat dinamis. Ketika ada temuan tentang pendekatan ketrampilan proses, atau Quantum Teaching misalnya, para pengembang pendidikan agama Islam banyak disibukkan oleh upaya adopsi dan modifikasi ke dalam pendidikan agama Islam, walaupun setiap bidang studi pada dasarnya memiliki karakteristiknya sendiri.

Untuk memahami diskursus tentang kualitas pendidikan agama tersebut dapat dibaca dalam maka-lah-makalah dan buku-buku berikut: (1) Soedjatmoko, Pengaruh Pendidikan Agama Terhadap Kehidupan Sosial, "Makalah" Disa-jikan Pada Seminar Pendidikan Agama dan Sistem Pendidikan Bangsa, Jakarta 28-31 Januari 1976; (2) Rosyidan, Pandangan para Siswa, Guru dan Orang Tua Siswa Terhadap Perilaku Negatif Remaja, Pidato Dies Natalis XXXVI IKIP Malang, 18 Oktober 1990; (3) Mochtar Buchori, Posisi dan Fungsi Pendi-dikan Agama Islam dalam Kurikulum Perguruan Tinggi Umum, "Makalah" pada Seminar Nasional di IKIP Malang, 24 Februari 1992; (4) Harun Nasution, Islam Rasional Gagasan dan Pemi-kiran (Bandung: Mizan, 1995); (5) Rasdijanah, Butir-butir 
Pengarahan Dirjen Binbaga Islam pada Pelatihan Peningkatan Wawasan Ilmu Pengetahuan dan Kependidikan Bagi Dosen PAI di Perguruan Tinggi Umum, Bandung, 11 Desember 1995; (6) Siti Malikhah Thawaf, Pembinaan Kampus Sebagai Lembaga Pendidikan Ilmiah Edukatif yang Religius, "Makalah" pada Konvensi Nasional Pendidikan Indonesia III, Ujung Pandang 4-7 Maret 1996; (7) Amin Abdullah, Problem Epistemologis-Metodologis Pendidikan Islam, dalam Abdul Munir Mulkhan, et. al., Reli-giusitas Iptek (Yogyakarta: Pustaka Pelajar, 1998); (8) Komaruddin Hidayat, Memetakan Kembali Strukiur Keilmuan Islam (Kata Pengantar), dalam Fuaduddin \& Cik Hasan Bisti (ed.), Dinamika Pemikiran Islam di Perguruan Tinggi: Wacana Tentang Pendidikan Agama Islam (Jakarta: Logos, 1999); (9) Muhaimin, et. al., Paradigma Pendidikan Islam Upaya Mengefektifkan Pendidikan Agama Islam Di Sekolah (Bandung: Remaja Rosdakarya, 2001).

Persoalan ketiga menyangkut upaya membangun pendidikan Islam secara terpadu untuk mengembangkan manusia Indonesia seutuhnya. Dalam konteks ini, Karim menyatakan bahwa pendidikan Islam di beberapa negara Islam - yang mayoritas penduduknya beragama Islam termasuk Indonesia - tidak lebih dari duplikasi terhadap pendidikan di negara-negara Barat sekuler yang banyak mereka cela. Dengan demikian produk sistem pendidikan mereka tidak mungkin menjadi atau berupa alternatif. Karena itu, tantangan yang mendasar bagi pendi-dikan Islam saat ini adalah mencari sistem pendidikan alter-natif sebagai sintesa dari berbagai sistem pendidikan yang pernah ada. ${ }^{20}$ Bagaimana wujud sintesa tersebut, rupanya Karim telah memberikan gambaran umum, yaitu perlunya pendidikan Islam yang lebih menitikberatkan pada aspek afektif seimbang dengan segi kognitif, serta memadukan secara harmonis pendidikan formal, non formal dan informal.

Sistem pendidikan di Indonesia yang tidak terlepas dari duplikasi terhadap pendidikan di negara-negara Barat tersebut diperkuat oleh hasil penelitian Idris yang menunjukkan bahwa sistem pendidikan di Indonesia sesuai dengan UU No. 4 tahun 1950 jo. UU No. 12 tahun 1954, secara teoretik banyak diwarnai oleh corak pemikiran filsafat humanism, karena elit pemikimya yang berasal dari didikan kolonialis Belanda atau Eropa, sehingga dalam praktiknya berkembang dualisme pendidikan, Islami dan sekuler. ${ }^{21}$

Adanya dualisme tersebut, menurut Ma'arif, juga tidak bisa dilepaskan dari pengaruh pemikiran pendidi-kan Islam warisan dari periode klasik akhir yang tidak 
lagi ditegakkan atas fondasi intelektual-spiritual yang kokoh dan anggun. Diterimanya dikotomi antara ilmu-ilmu agama dan ilmu-ilmu umum adalah di antara indikasi kerapuhan dasar filosofis pendidikan Islam pada saat itu. ${ }^{22}$ Karena itu, ia menyarankan agar secara teoretis filosofis pendidikan Islam melakukan pembaharuan dan menumbangkan konsep dualisme dikotomik secara mendasar antara apa yang dikategorikan ilmu-ilmu agama dan ilmu-ilmu sekuler, di mana ilmu-ilmu agama menduduki posisi fardlu 'ain dan ilmu-ilmu sekuler - paling tinggi - berada pada posisi fardlu kifayah, yang seringkali menjadi terabaikan. Jika dualisme dikotomik tersebut berhasil ditumbangkan, maka sistem pendidikan Islam akan berubah secara keseluruhan mulai dari tingkat dasar hingga perguruan tinggi. Untuk kasus IAIN akan lebur secara integratif dengan PTN, dalam arti bukan peleburan satu atap, tetapi lebur berdasarkan rumus filosofis. ${ }^{23}$

Dalam konteks historis, ketika kerajaan-kerajaan Eropa di Barat mengalami kemajuan serta mulai mengadakan penetrasi ke dunia Islam di Timur dan pada abad $19 \mathrm{M}$ sebagian besar dunia Islam berada di bawah kolonialisme Barat, maka pemi-kiran-pemikiran Barat banyak masuk ke dunia Islam dan ber-pengaruh dalam berbagai bidang kehidupan. Pemikiran Barat yang ketika itu banyak dipengaruhi oleh faham sekularisme, sedikit banyak juga masuk ke dalam lembaga-lembaga pendidi-kan, termasuk lembaga pendidikan di Indonesia yang banyak diwarnai oleh sistem pendidikan kolonial Belanda, yang lebih menekankan pada pendidikan intelektual dan mengabaikan pendidikan agama. Setelah dunia Islam memerdekakan diri dari kolonialisme tersebut, maka sistem pendidikan itu tidak banyak mengalami perubahan, sehingga peserta didik yang dihasilkannya tidak sesuai dengan jiwa Islam. ${ }^{24}$ Karena ifu diperlukan pemikiran untuk membahas dan mempelajari selukbeluk pendidikan yang sesuai dengan jiwa Islam.

Dari paparan di atas dapat diambil kesimpulan semen-tara bahwa corak pendidikan Islam yang diinginkan oleh mereka adalah: (1) sintesa dari berbagai sistem pendidikan yang pernah ada; (2) menumbangkan konsep dualisme dikotomik antara ilmu agama dan ilmu umum atau inelakukan integrasi antara keduanya; dan (3) sistem pendidikan yang sesuai dengan jiwa Islam.

Bagaimana format sintesa, integrasi dan sistem pendi-dikan yang sesuai dengan jiwa Islam tersebut? Dalam memecah-kan masalah ini Ma'arif menawarkan landasan filosofis pendidikan yang sepenuhnya berangkat dari cita-cita al-Qur'an tentang manusia, serta perlunya kegiatan pendidikan di bumi yang berorientasi ke 
langit (orientasi transenden-tal), yang harus tercermin secara tajam dan jelas dalam rumusan filsafat pendidikan Islam, agar kegiatan pendidikan mempunyai makna spiritual yang mengatasi ruang dan waktu ${ }^{25}$. Karim menawarkan tauhid sebagai landasan filosofis pendidikan Islam ${ }^{26}$. Gagasan ini sebenamya telah lama ditawarkan oleh M. Natsir (1908-1993 M), sebagaimana dikemukakan oleh Tarmizi Taher, dkk. dalam bukunya "Pemikiran dan Perjuangan Mohammad Natsir". Domikian pula Rahardja, dalam kajiannya tentang Tauhid dan Pendidikan, ia berkesimpulan bahwa untuk bisa menghasilkan suatu pribadi yang integral melalui proses pendidikan, berbagai konsep tauhid (Uluhiyah, Rububiyah, Mulkiyah dan Rahmaniyah) perlu diintegrasikan menjadi suatu konsep tauhid yang holistik ${ }^{27}$.

Dengan bahasa yang berbeda tetapi mempunyai makna yang sama, Mastuhu menyebut pendidikan Islam berangkat dari filsafat pendidikan theocentric. Ciriciri filsafat pendidikan theocentric adalah: (1) ia mengandung dua jenis nilai, yaitu nilai kebenaran absolut, yaitu wahyu Tuhan; dan nilai kebenaran relatif, yaitu hasil penafsiran manusia terhadap wahyu Tuhan. Karena itu, kedua nilai itu mempunyai hubungan hierarchis, yakni nilai kebenaran absolut merupakan supremasi terhadap kebenaran relatif, dan kebenaran relatif tidak boleh bertentangan dengan nilai absolut (aqidah-syar-iah agama); (2) ia memandang bahwa semua yang ada diciptakan olehNya, berjalan menurut hukumNya, dan kembali kepada kebenaranNya; (3) ia memandang bahwa manusia dilahirkan sesuai dengan fitrahnya dan perkembangan selanjutnya tergan-tung pada lingkungan dan pendidikan yang diperolehnya; (4) ia mendasarkan kegiatan pendidikannya pada tiga nilai kunci, yaitu ibadah, ikhlas dan ridla Tuhan; (5) manusia dipandang secara utuh dan dalam kesatuan diri dengan kosmosnya sebagai makhluk pencari kebenaran Tuhan; (6) kegiatan belajarmenga-jar dipandang sebagai bagian dari totalitas kehidupan, merupakan kewajiban yang tidak mengenal batas selesai dan merupakan ibadah kepada Tuhan. ${ }^{28}$

Berbagai tawaran tersebut pada dasarnya berada dalam satu arus pemikiran yang sama, yang intinya bahwa pendidikan Islam bermuara pada prinsip ajaran dan nilai-nilai ketauhi-dan. Namun demikian, diperlukan rumusan yang jelas dan terinci mengenai filsafat pendidikan Islam yang bertolak dari prinsip tersebut, sehingga dapat dijadikan landasan operasional dalam pelaksanaan sistem pendidikan Islam. Agaknya mereka baru memberikan gagasan-gagasan awal yang perlu dikembangkan dalam kajian-kajian lanjut yang lebih mendalam. Sejak tahun 1985 Noeng Muhadjir telah menawarkan alternatif bangunan konsep filosofiknya dalam 
upaya mengin-tegrasikan wawasan Islam dan ilmu pengetahuan. Hal ini perlu ditindaklanjuti dengan kajian-kajian khusus dalam konteks filsafat pendidikan Islam. ${ }^{29}$

Persoalan keempat menyangkut penggalian konsep pemi-kiran filosofis pendidikan Islam serta pemikiran tokoh-tokoh pendidikan Islam mulai periode klasik hingga periode modern, baik dari dalam maupun luar negeri. Kajian ini banyak dilakukan oleh mahasiswa-mahasiswa S2 dan S3 IAIN yang mengambil konsentrasi pendidikan Islam. Di samping itu, terdapat buku-buku pemikiran para tokoh pendi-dikan Islam, sebagaimana dalam antologi berjudul "Pemikiran Pendidikan Islam Kajian Tokoh Klasik dan Kontemporer" yang ditulis oleh dosen-dosen Fakultas Tarbiyah IAIN Semarang; buku "Pemikiran Para Tokoh Pendidikan Islam (Seri Kajian Filsafat Pendidikan Islam)" oleh Abuddin Nata, buku-buku "Filsafat Pendidikan Islam" karya Jalaluddin, Abuddin Nata, pada akhir pembahasannya juga membahas tokoh-tokoh pendidikan Islam tersebut; dan buku Hasan Langgulung, Manusia dan Pendidikan, juga memuat tokoh-tokoh pendidikan Islam. Upaya penerjemahan buku-buku berbahasa asing juga dilakukan untuk penggalian pemikiran tokoh-tokoh pendidikan Islam, antara lain buku "Arabic Contributions to Educational Thought" oleh Tedd D. Beavers, dan lain-lain.

Di sisi lain, masuknya mata kuliah "Filsafat Pendidi-kan Islam" atau "Sejarah dan Filsafat pendidikan Islam" ke dalam kurikulum Fakultas Tarbiyah IAIN sejak tahun 1960-an hingga sekarang juga mendorong para dosen untuk menggali lebih jauh tentang Filsafat Pendidikan Islam. Buku "Pengan-tar Filsafat Pendidikan Islam" karya Ahmad D. Marimba adalah buku pertama yang disusun sejak tahun 1962, yang banyak dijadikan acuan dalam mata kuliah tersebut, di samping bukubuku lainnya yang berbahasa Arab atau berasal dari Timur Tengah. Sebagian bukubuku berbahasa Arab tersebut kemudian diterjemahkan ke dalam bahasa Indonesia, seperti buku "Al-Tarbiyah al-Islamiyah" karya Al-Abrosyi, yang diterjemahkan oleh Bustami A. Gani pada tahun 1970 dengan judul "Dasar-Dasar pokok Pendidikan Islam", buku "Mabadi' al-Tarbiyah al-Islamiyah" karya Asma Hasan Fahmi, yang diterjemahkan oleh Ibrahim Husein pada tahun 1979, dengan judul "Sejarah dan Filsafat Pendidikan Islam", buku "Falsa-fah al-Tarbiyah al-Islamiyah" karya Al-Syaibani yang diter-jemahkan oleh Hasan Langgulung pada tahun 1979, dan lain-lainnya.

Karya-karya pendidikan Islam yang sebagiannya menyinggung filsafat pendidikan, atau yang berbau pemikiran, dan/atau yang berlabel "Filsafat Pendidikan 
Islam" mulai berkembang sejak tahun 1980-an, seperti "Prinsip Dasar Konsepsi Pendidikan Islam" karya Syahminan Zaini (1986), "Filsafat Pendidikan Islam" karya M. Arifin (1987), "Filsa-fat Pendidikan Islam" oleh Tim Proyek Dibinpertais (1984), karya-karya Hasan Langgulung, seperti Asas-Asas Pendidikan Islam (1988), Pendidikan Islam Menghadapi Abad Ke 21 (1988), Manusia Dan Pendidikan (1986), Beberapa Pemikiran tentang Pendidikan Islam (1980), atau antologi kecil yang berasal dari kumpulan-kumpulan makalah seminar, seperti: "Tantangan Pendidikan Islam".

Namun demikian, buku-buku yang khusus membahas ten-tang "Filsafat Pendidikan Islam" agaknya masih terbatas jumlahnya, bahkan pada tahun 1990-an hanya ditemukan 2 buku yang khusus membahas filsafat pendidikan Islam, yaitu: "Filsafat Pendidikan Islam" karya Jalaluddin \& Usman Said (1994), dan "Filsafat Pendidikan Islam" karya Abuddin Nata (1997). Selainnya masih bersifat pengantar, seperti "Para-digma Intelektual Muslim Pengantar Filsafat Pendidikan Islam dan Dakwah" karya Abdul Munir Mulkhan (1993). Atau bukubuku yang mengandung unsur pemikiran (filsafat), seperti: Pemikiran Pendidikan Islam (Kajian Filosofis dan Kerangka Dasar Operasionalnya) karya Muhaimin \& Abdul Mudjib (1993), Konsep Pendidikan Islam Sebuah Telaah Komponen Dasar Kurikulum, karya Muhaimin (1993), "Kreativitas dan Pendidikan Islam Analisis Psikologi dan Falsa-fah" karya Hasan Langgulung (1990), Ilmu Pendidikan dalam Perspektif Islam karya A. Tafsir (1992), Visi Pembaharuan Pendidikan Islam karya A. Malik Fadjar (1998), Pendidikan Islam Tradisi dan Modernisasi Menuju Millenium Baru karya Azyumardi Azra, Memberdayakan Sistem Pendidikan Islam karya Mastuhu, dan lain-lain.

Dari berbagai karya tentang pendidikan Islam tersebut di atas, yang sempat ditelaah oleh Azra, menunjukkan bahwa pola kajian pemikiran dan teori kependidikan Islam di Indonesia memiliki beberapa kecenderungan, yaitu: (1) mendekatinya secara sangat doktrinal, normatif dan ide-alistik, yang kadang-kadang justeru mengaburkan kaitan atau konteksnya dengan pendidikan Islam itu sendiri; (2) menga-dopsi filsafat, pemikiran dan teori kependidikan Barat, tanpa kritisisme yang memadai, bahkan hampir terjadi pengambilan mentah-mentah; (3) memberi legitimasi terhadap pemi-kiran dan filsafat pendidikan Barat dengan ayat al-Qur'an dan hadits tertentu, sehingga yang menjadi titik tolak adalah pemikiran kependidikan Barat (bukan pemikiran kepen-didikan Islam), yang belum tentu kontekstual dan 
relevan dengan pemikiran kependidikan Islam; (4) pemikiran kependidikan Islam atau yang relevan dengannya yang dikembangkan para ulama, pemikir dan filosof muslim sedikit sekali diung-kap dan dibahas. ${ }^{30}$

Azxa $\mathrm{a}^{31}$ juga mengamati adanya diskursus kritis tentang pendidikan Islam dalam konteks perkembangan mutakhir, seba-gaimana terlihat dalam antologi kecil berjudul "Pendidikan Islam di Indonesia Antara Cita dan Fakta". Menurut Azra, buku ini mencakup artikel-artikel yang "thought pro-voking", misalnya: tulisan A. Syafii Maarif "Pendidikan Islam sebagai Paradigma Pembebasan", dan M. Rusli Karim "Pendidikan Islam sebagai Upaya Pembebasan Manusia". Kedua artikel tersebut sedikit banyak diilhami oleh Paulo Freire tentang pendidikan dan pembebasan manusia dari ketertindasan struktural dan kultural, yang merupakan awal yang baik bagi pengembangan konsepsi dan pemikiran kependidikan Islam yang lebih dinamis dan fungsional dalam menjawab tantangan-tantangan dunia pendidikan umumnya dewasa ini dan abad 21 .

\section{Kesimpulan}

Dari berbagai uraian tersebut di atas dapat diambil kesimpulan sebagai berikut:

1. Dalam realitas sejarahnya, sejak awal kemerdekaannya bangsa Indonesia telah memberikan perhatian dan pengakuan yang relatif tinggi terhadap sumbangan besar pendidikan Islam dalam upaya mendidik dan mencerdaskan kehidupan bangsa. Hal ini di samping merupakan prestasi tersendiri yang telah diraih oleh umat Islam, juga sekaligus merupa-kan tantangan yang memerlukan respon positif dari para pemikir dan pengelola pendidikan Islam di Indonesia.

2. Bangsa Indonesia yang telah mewarisi sistem pendidikan dan pengajaran yang dualistis (sistem pendidikan Islam dan kolonial), ternyata tidak memberikan perioritas kepada salah satunya, tetapi berusaha mengintegrasikan keduanya menjadi "satu sistem pendidikan nasional". Dengan disahkannya UU No. 2 tahun 1989, tentang Sistem Pendidikan Nasional, maka integrasi pendidikan Islam ke dalam sistem pendidikan nasional menda-patkan dasar hukumnya yang mantap, baik dari aspek 
kelembagaan maupun isi kurikulumnya, di mana setiap jenis, jalur dan jenjang pendidi-kan wajib memuat pendidikan agama (Islam).

3. Diskursus pengembangan pendidikan Islam yang menjadi perhatian dari para pengembang dan pemikirnya, baik yang menyangkut dikotomi ilmu pengetahuan hingga memun-culkan isu islamisasi ilmu pengetahuan, masalah kualitas pendidikan agama Islam di sekolah atau perguruan tinggi umum, upaya membangun pendidikan Islam secara terpadu, dan upaya penggalian konsep filosofis pendidikan Islam dan pemikiran tokoh-tokoh pendidikan Islam sejak periode klasik hingga periode modern, baik dari dalam maupun dari luar negeri, agaknya semakin mem-perkaya khazanah pemikiran tentang pengembangan pendidi-kan Islam di Indonesia, dan sekaligus akan lebih mendukung dan semakin mempertajam serta memperkokoh eksistensi bangunan pendidikan Islam sebagai disiplin ilmu yang berdiri sendiri.

\section{Endnotes}

1 Baca Fazlurrahman, Islam (Chicago: The University of Chicago Press, 1979), 260

- Faisal Ismail, Paradigma Kebudayaan Islam: Studi Kritis dan Refleksi Historis (Yogyakarta: Titian Ilahi Press, 1996), 31.

3 Dari hasil kajian penulis menunjukkan bahwa salah satu corak pengembangan pendidikan Islam sebelum Indonesia merdeka ialah bercorak Isolatif-Tradisional, dalam arti tidak mau menerima apa saja yang berbau Barat (kolonial) dan terhambatnya pengaruh pemikiran-pemikiran modern dalam Islam untuk masuk ke dalamnya, sebagaimana tampak jelas pada pendidikan pondok pesantren tradisional yang hanya meno-njolkan ilmu-ilmu agama Islam dan pengetahuan umum sama sekali tidak diberikan. Hakekat pendidikan Islam adalah sebagai upaya melestarikan dan mempertahankan khazanah pemikiran ulama terdahulu sebagaimana tertuang dalam kitab-kitab mereka. Tujuan utama pendidikannya adalah menyiapkan calon-calon kiyai atau ulama yang hanya menguasai masalah agama semata.

* Sintesis maksudnya adalah corak pengembangan pendidikan Islam yang berusaha mempertemukan antara corak lama (pondok pesantren) dan corak baru (model pendidikan kolonial atau Barat) yang berwujud sekolah atau Madrasah. Hasil kajian penulis menunjukkan bahwa corak pemikiran sintesis berkembang dalam berbagai variasi, yaitu: (1) pola pengembangan pendidikan madrasah mengikuti format pendidikan Barat terutama dalam sistem pengajarannya secara klasikal, tetapi isi pendidikan tetap lebih menonjolkan ilmu-ilmu agama Islam, sebagaimana dikembangkan 
pada Madrasah Sumatera Thawalib dan Madrasah Tebu Ireng pimpinan KH. Hasyim Asy"ari; (2) pola pengemban-gan pendidikan madrasah yang mengutamakan mata pelajaran-mata pelajaran agama, tetapi mata pelajaran-mata pelajaran umum secara terbatas juga diberikan, seperti yang dikembang-kan oleh Madrasah Diniyah Zaenuddin Lebau el-Yunusi dan Madrasah Salafiyah Tebu Ireng pimpinan KH. Ilyas; (3) pola pengembangan pendidikan Madrasah yang menggabungkan secara lebih seimbang antara muatan-muatan keagamaan dan non keaga-maan, seperti yang dikembangkan oleh Pondok Muhammadiyah; dan (4) pola pengembangan pendidikan sekolah yang mengikuti pola gubernemen dengan ditambah beberapa mata pelajaran agama, sebagaimana dikembangkan oleh Madrasah Adabiyah (Adabiyah School) dan sekolah Muhammadiyah.

5. Selo Sumardjan, Perubahan Sosial di Yogyakarta (Yogyakarta: Gajahmada University Press, 1981), 278.

6. Sugarda Purbakawaca, Pendidikan dalam Alam Indonesia Merdeka (Jakarta: Gunung Agung, 1970), 39.

7. Endang Saifuddin Anshari, Piagam Jakarta 22 .Juni 1945 (Bandung: Pustaka, 1981), 26-27. Endang Saifuddin Anshari, Piagam Jakarta 22 Juni 1945 (Bandung: Pustaka, 1981), 26-27.

8. Walaupun secara formal kalimat yang menyatakan "dengan kewajiban menjalankan syariat Islam bagi segenap pemeluknya" (yang berasal dari rumusan Piagam Jakarta) diha-puskan dalam Pembukaan UUD 1945, namun jiwa dan semangatnya tetap menyatu dan menjiwai semua ketentuan dalam UUD terse-but. Hal ini sebagaimana tercermin dalam Penjelasan UUD 1945 dan yang secara tegas dinyatakan dalam Dekrit Presiden 5 Juli 1959, sewaktu memberlakukan kembali UUD 1945. Lihat: Departemen Penerangan RI, Tujuh Bahan Pokok Indoktrinasi (Jakarta: Dep. Penerangan RI, 1961), 57 dan 107.

9. Pasal 29 ayat 2 UUD 1945 menyatakan bahwa: "Negara menjamin kemerdekaan tiaptiap penduduk untuk memeluk aga-manya masing-masing dan untuk beribadat menurut agamanya dan kepercayaannya itu".

10. Anton Timur Djailani, Peningkatan Mutu Pendidikan dan Pembangunan Agama (Jakarta: Dermaga, 1982), 21.

11. M. Said, Pendidikan Abad Keduapuluh Dengan Latar Belakang Kebudayaannya (Jakarta: Mutiara, 1981), 10.

12. Ibid., 10-13.

13. Anton Timur Djailani, Peningkatan Mutu Pendidikan, 21.

14. Departemen Pendidikan dan Kebudayaan, Pendidikan di Indonesia dari Jaman ke Jaman (Jakarta: Dep. P \& K, 1979), 94. 
15. Maksum, Madrasah Sejarah dan Perkembangamya (Jakarta: Logos Wacana Ilmu, 1999), 123.

16. Lembaga Penelitian IAIN Jakarta, Islam dan Pendidi-kan Nasional (Jakarta: IAIN, 1983), 141.

17. Mochtar Buchori, Pendidikan Islam di Indonesia: Problema Masa Kini dan Perspektif Masa Depan, dalam M. Dawam Rahardjo, Peng., Islam Indonesia Menatap Masa Depan (Jakar-ta: P3M, 1989), 189.

18. A Syafii Maarif, et. al., Pendidikan Islam di Indonesia Antara Cita dan Fakta (Yogyakarta: Tiara Wacana, 1991).

19. Syed M. Naquib Al-Attas, Islam dan Sekularisme (Bandung: Pustaka, 1981), 195; Syed Sajjad Husein \& Syed Ali Ashraf, Krisis Pendidikan Isiam, terj. (Bandung: Risalah, 1986), 125-129; dan Isma'il Raji Al-Faruqi, Islamisasi Pengetahwan, terj. (Bandung: Pustaka, 1984), 11.

20. M. Rusli Karim, Pendidikan Islam Sebagai Upaya Pembebasan Manusia, dalam A. Syafii Maarif, et. al., Pendi-dikan Islam di Indonesia, 37.

$\therefore$ Safwan Idris, "Tokoh-Tokoh Nasional, Overseas Education and Evolution of the Indone sian Educated Elite" (Disertasi, The University of Wiscousin-Madison, Ph.D., 1982).

22 A. Syafii Ma'arif, Peta Bumi Intelektualisme Islam di Indonesia (Bandung: Mizan, 1993), 144.

23 A. Syafii Maarif, et. al., Pendidikan Islam di Indonesia, 149-150.

24. Harun Nasution, et. al., Islam dan Pendidikan Nasional, 13-14.

25 A. Syafii Maarif, Pendidikan Islam, 149-155.

26 Ib id., 31 .

17 M. Dawam Rahardjo, Intelektual Inteligensia Dan Perilaku Politik Bangsa Risalah Cendekionwan Muslim (Bandung: Mizan, 1993), 430-442.

28 Mastuhu, Dinamika Sistem Pendidikan Pesantren Suatu Kajian Tentang Unsur dan Nilai Sistem Pendidikan Pesantren (Jakarta: INIS, 1994), 16-17.

29 Baca Noeng Muhadjir, Pendidikan IImu dan Islam (Yogyakarta: Rake Sarasin, 1985), 1-15; lihat pula Noeng Muhadjir, Mengintegrasikan Wawasan Islam dan Ilmu Pengeta-huan, dalam Ahmad Busyairi, ed., Tantangan Pendidikan Islam (Yogyakarta: Lembaga Pers Mahasiswa UI, 1987), 107-114.

30 Azyumardi Azra, Pendidikan Islam Tradisi dan Moder-misasi Mentju Milenium Baru (Jakarta: Logos, 1999), 91.

31 Lihat: $I b$ id. 


\section{Bibliography}

Al-Attas, Syed M. Naquib, 1981, Islam dan Sekularisme, Bandung: Pustaka

Fazlurrahman, 1979. Islam, Chicago: The University of Chicago Press

Husein, Syed Sajjad \& Syed Ali Ashraf, 1986, Krisis Pendidikan Islam, terj. Bandung: Risalah

Ismail, Faisal. 1996. Paradigma Kebudayaan Islam: Studi Kritis dan Refleksi Historis Yogyakarta: Titian Ilahi Press

Lembaga Penelitian IAIN Jakarta, 1983, Islam dan Pendidikan Nasional, Jakarta: IAIN

Djailani, Anton Timur. 1982. Peningkatan Mutu Pendidikan dan Pembangunan Agama Jakarta: Dermaga

M. Said, Pendidikan Abad Keduapuluh Dengan Latar Belakang Kebudayaannya (Jakarta: Mutiara, 1981

Departemen Pendidikan dan Kebudayaan, 1979. Pendidikan di Indonesia dari Jaman ke Jaman, Jakarta: Dep. P \& K

Maarif, A. Syaf'i. et.al., 1991. Pendidikan Islam di Indonesia Antara Cita dan Fakta Yogyakarta: Tiara Wacana

Maksum, 1999. Madrasah Sejarah dan Perkembangannya, Jakarta: Logos Wacana Ilmu

Rahardjo, M. Dawam, 1989. Peng., Islam Indonesia Menatap Masa Depan, Jakar-ta: P3M 